\title{
Inhibitory effects of salmonid tissue on the growth of Renibacterium salmoninarum
}

\author{
J. G. Daly, R. M. W. Stevenson \\ Department of Microbiology, College of Biological Sciences, University of Guelph, Guelph, Ontario, Canada N1G 2 W1
}

\begin{abstract}
The presence of fish tissue in the inoculum inhibited growth of Renibacterium salmoninarum when samples were plated on charcoal-containing KDM-C agar. The inhibition was similar to that seen on serum-containing medium (KDM-2). Liver and kidney tissues from rainbow trout, brook trout, and coho salmon inhibited growth unless samples were diluted. The inhibition could not be removed by adding activated charcoal directly to tissue. Inhibition due to tissues of rainbow trout, but not those of coho salmon or brook trout, could be removed by spreading out spot inocula on the agar surface.
\end{abstract}

\section{INTRODUCTION}

Renibacterium salmoninarum, the agent of bacterial kidney disease (BKD) of salmonid fishes, is fastidious in its growth requirements and has been generally cultured on such media as KDM-2, containing serum and cysteine (Evelyn 1977). Under ideal conditions, and with a heavy inoculum, growth appears on agar after approximately $10 \mathrm{~d}$. With light inocula, growth may not be evident before 6 wk (Fryer \& Sanders 1981). Isolation of the bacterium from infected fish is further complicated by the inhibitory effects of kidney tissue from coho salmon Oncorhynchus kisutch and sockeye salmon (O. nerka) towards $R$. salmoninarum (Evelyn et al. 1981). Growth was inhibited unless tissue samples were washed and/or diluted. When homogenized tissue was washed in peptone-saline and collected by centrifugation, the inhibitory activity (hereafter referred to as tissue toxicity) was found in the supernatant fraction.

One purpose of this study was to determine whether tissue toxicity occurred with other salmonid genera, particularly the widely cultured rainbow trout. Another purpose was to find out whether the tissue toxicity was also seen when samples were plated on a serum-free charcoal agar (KDM-C) developed for the culture of Renibacterium salmoninarum (Daly \& Stevenson 1985). If charcoal replaces serum by acting as a detoxifying agent, use of KDM-C might relieve the observed tissue toxicity and eliminate the necessity for laborious washing. Thus, we examined the effect of charcoal on tissue toxicity by adding it directly to the growth medium and by adding it (as an inoculum pre-treatment) directly to the tissue homogenate serving as the inoculum.

\section{MATERIALS AND METHODS}

Liver and kidney tissues from rainbow trout Salmo gairdneri and brook trout Salvelinus fontinalis were obtained from BKD-free laboratory stocks. Coho salmon Oncorhynchus kisutch were obtained from a hatchery where BKD was a chronic problem. All fish were held in running well-water at approximately $10^{\circ} \mathrm{C}$. Fish were killed by an overdose of MS-222 in water, and liver and kidney tissues were aseptically removed, placed in sterile plastic bags (Whirl-Pak ${ }^{(\mathbb{8})}$, and weighed.

To artificially seed tissues with bacteria, a culture of Renibacterium salmoninarum ATCC 33209 was grown biphasically on KDM-C for 10 to $14 \mathrm{~d}$, as described previously (Daly \& Stevenson 1985). For the agar and all other procedures, the activated charcoal used was an untreated powder form, C-5260 from Sigma Chemical Co., St Louis, MO, USA. A bacterial suspension was made by adding $1 \mathrm{ml}$ of the liquid overlay phase from a culture to $100 \mathrm{ml}$ of peptone-saline $(0.1 \%$ peptone in $0.85 \% \mathrm{NaCl}$ ). The suspension was added to rainbow and brook trout tissues in the plastic bags at ratio of $0.1 \mathrm{ml}$ to $0.1 \mathrm{~g}$ of tissue. The mixtures were homogenized for approximately 2 min with a mechanical stomacher (Seward Laboratory, London, England). 
As the coho salmon were naturally infected with $R$. salmoninarum, these tissues did not require artificial seeding. They were treated in the same manner except that sterile peptone-saline was used rather than the bacterial suspension

In the experiments to determine if tissues could be directly treated with charcoal to remove toxicity, $0.1 \mathrm{~g}$, $1 \mathrm{~g}$ or $2 \mathrm{~g}$ of charcoal was added to $100 \mathrm{ml}$ of peptonesaline. To this suspension, $1 \mathrm{ml}$ of biphasically grown bacteria was added, and the charcoal, peptone-saline, bacterial mixture was immediately added to the tissue at a ratio of $01 \mathrm{ml}$ to $0.1 \mathrm{~g}$ of tissue, providing a $1 / 2$ tissue homogenate. The tissue homogenates were diluted further by making serial doubling dilutions to $1 / 64$ in peptone saline. Two $25 \mu \mathrm{l}$ samples of each dilution were then spot-inoculated onto KDM-C agar plates, 3 dilutions per plate. Inoculated plates were allowed to dry overnight in a $15^{\circ} \mathrm{C}$ incubator, then placed in bags to prevent dehydration during further incubation at $15^{\circ} \mathrm{C}$ for $1 \mathrm{mo}$.

\section{RESULTS AND DISCUSSION}

Liver and kidney tissue from rainbow trout, brook trout, and coho salmon were all toxic towards Renibacterium salmoninarum when tested on charcoal agar. As with the previous KDM-2 studies by Evelyn et al. (1981), toxicity disappeared when the tissues were diluted to $1 / 4$ or $1 / 8$ of their original $1 / 2$ concentration. These findings demonstrate that tissue toxicity affecting $R$. salmoninarum occurs not only in isolations from Oncorhynchus nerka and $O$. kisutch, as described by Evelyn et al. (1981), but in those from other salmonids as well. Toxicity was not restricted to kidney tissue and is potentially present in all organ tissues.
The charcoal agar, KDM-C, does not appear to be any better than KDM-2 in its ability to reduce tissue toxicity. Attempts to remove the toxicity by mixing charcoal directly with the tissues during homogenization in peptone-saline were unsuccessful with concentrations of charcoal up to and including $2 \%$. Higher concentrations of charcoal could not be used because of the danger of puncturing the bags containing the tissue during stomaching.

Increasing the concentration of charcoal in KDM-C agar to 0.5 or $1 \%$ also failed to eliminate toxicity and, at these concentrations, the spot-inocula began to bead up on the agar surface. When rainbow trout homogenates were cultured on KDM-C plates, it appeared that the toxicity was reduced if the spot invculd were more spread out. The bacteria appeared to grow well at the outer edge of the spot-inoculum. This suggested that the toxicity might be reduced by actively streaking out the inocula; in effect, doing an in situ dilution of the tissue. Thus, the $25 \mu \mathrm{l}$ spot inocula were spread with an inoculating loop, such that each spot covered about one-sixth of the plate. With both liver and kidney tissue, this procedure did allow growth of the bacteria at the $1 / 2$ dilution, when it would otherwise have been inhibited (Fig. 1). Similar results were obtained consistently in trials of the procedure.

The spreading technique was, however, not very effective in reducing the toxicity of coho salmon and brook trout tissues. Spreading of the $1 / 8$ dilution resulted in growth, but not consistently. It is not evident why the tissues of rainbow trout are different from those of brook trout or coho salmon, nor is it known whether in situ tissue dilution will reduce the toxic effect of tissues of all strains of rainbow trout. However, it would still seem to be a useful procedure to spread out spot inocula on agar plates in order to separate
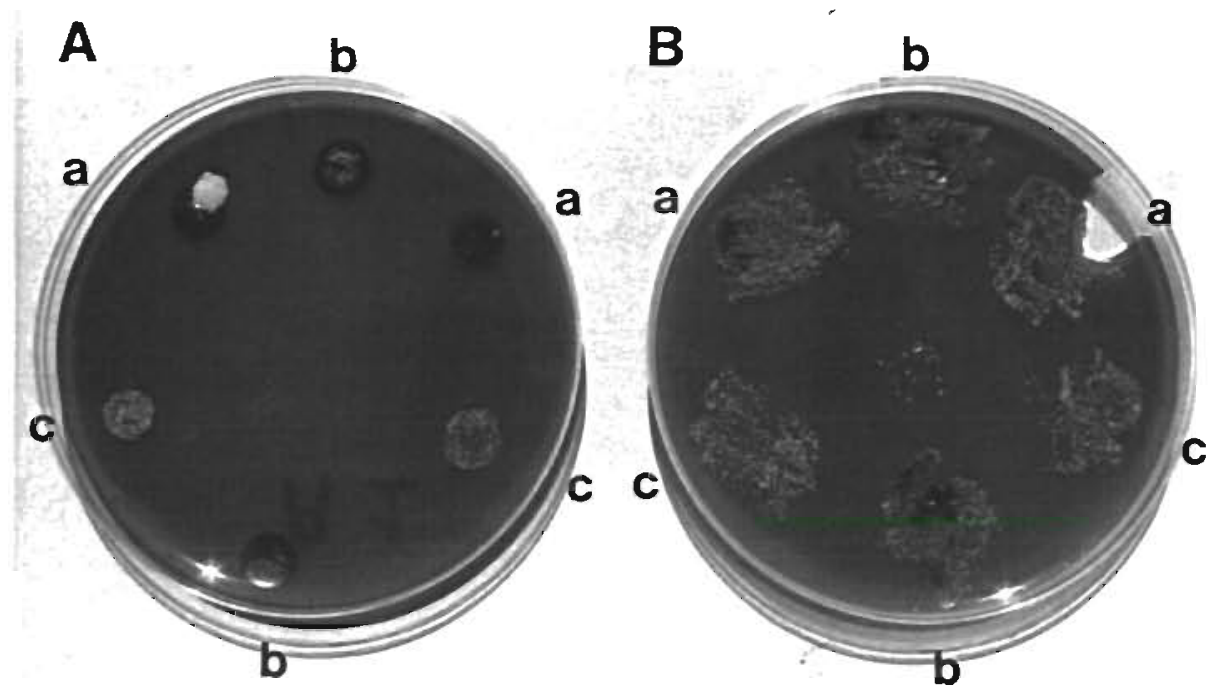

Fig. 1. Growth on KDM-C agar from dilutions of rainbow trout kidney homogenate seeded with Renibacterium salmoninarum. For Plate A, the $25 \mu \mathrm{J}$ drops served directly as inocula for $B$, they were spread with a sterile loop. The dilutions of tissue were: (a) $1 / 2$, (b) $1 / 4$, and (c) $1 / 8$. The white contaminant colony at the top of plate A (position a) illustrates one of the problems of prolonged incubation; earlier, a spreading contaminant had been excised from Plate B (a) 
bacteria from tissue when attempting to culture Renibacterium salmoninarum from tissues.

In coho salmon, we have noticed that when there are large numbers of bacteria in a tissue sample, as in a pustule, toxicity may not be apparent. In this case, the toxic material may be bound up by the sheer numbers of bacteria present, or perhaps little tissue remains to provide the toxicity. Austin \& Rayment (1985) did not detect toxicity in their work with rainbow trout tissue samples, but the inocula, collected on swabs, contained only small amounts of tissue and the tissue was not homogenized. Direct addition of charcoal to our larger tissue samples did not remove toxicity, but this may have been a function of the amounts of tissue relative to charcoal present and the release of more toxic materials by homogenization. Thus, the toxic load may have been too high to be absorbed adequately by the charcoal. The nature of the toxic component in tissues is still unknown; however, the hydrophobic cell surface of Renibacterium salmoninarum (Daly \& Stevenson 1987) would facilitate the binding of toxic fatty acids liberated from the tissues by homogenization.
Acknowledgements. This work was supported by a research grant from the Great Lakes Fisheries Commission. We thank Ken Gallant for his assistance with the work.

\section{LITERATURE CITED}

Austin, B., Rayment, J. (1985). Epizootiology of Renibacterium salmoninarum, the causal agent of bacterial kidney disease in salmonid fish. J. Fish Dis. 8: 505-509

Daly, J. G., Stevenson, R. M. W. (1985). Charcoal agar, a new growth medium for the fish disease bacterium Renibacterium salmoninarum. Appl environ. Microbiol 50:868-871

Daly, J. G., Stevenson, R. M. W. (1987). Hydrophobic and haemagglutinating properties of Renibacterium salmoninarum. J. gen. Microbiol. 133: 3575-3580

Evelyn, T. P. T. (1977). An improved growth medium for the kidney disease bacterium and some notes on using the medium. Bulletin de l'Office International des Epizooties 87: $511-513$

Evelyn, T. P. T., Ketcheson, J. E., Prosperi-Porta, L. (1981). The clinical significance of immunofluorescence-based diagnoses of the bacterial kidney disease carrier Fish Pathol. 15: $293-300$

Fryer, J. L., Sanders, J. E. (1981). Bacterial kidney disease of salmonid fish. Ann. Rev. Microbiol. 35: 273-298 